\title{
Mosaiikkinen kuva aikuiskasvatuksesta demokratian ja tasa-arvon takomona
}

\author{
Risto Rinne ja Arto Jauhiainen (toim.) (2011). Aikuiskasvatus ja demokratian haaste. \\ Aikuiskasvatuksen Tutkimusseura. Helsinki: Kansanvalistusseura, 269 s.
}

AIKUISKASVATUKSEN Tutkimusseura on päättänyt käsitellä aikuiskasvatuksen kysymyksiä neljän SAKKE-hankkeen (suomalaisen aikuiskasvatuksen kentät ja kerrostumat) teoksen voimalla. Kansanvalistusseura on ainakin teossarjan ensimmäisen osan kustantajana. Kirjan teemana on demokratian haaste. Myöhemmin ilmestyvät teokset käsittelevät aikuiskasvatuksen muuttuvia paradigmoja, aikuiskasvatuksen vaikuttajia sekä aikuisten kasvua ja aktivointia. Julkaisuilla pyritään varmasti luomaan tärkeää aikuiskasvatuksen ajankuvaa teemoista, joista kaikista ei edes ole aikaisempaa yhteistä julkaisua.

Pääasiassa turkulaiset tutkijat ottavat kiinni tasa-arvon kysymyksestä sosiologisesti painottuvalla otteella kirjasarjan ensimmäisessä osassa Aikuiskasvatus ja demokratian haaste. Teoksessa on vahvaa jatkumoa osallistumistutkimuksen perinteeseen, jota korostavat vielä muutamat juurevat historialliset katsaukset. Demokratian ja koulutuksellisen tasa-arvon kysymys onkin toiminut vuosikymmeniä eräänä kantavana aikuiskasvatuksen ja etenkin kansansivistystyön päämääränä ja innoituksen antajana. Ajankuvaa on tässä julkaisussa piirretty 11 tohtorin voimalla (joista kaksi naista) ja 10 artikkelin kautta. Ajankuvan arkkitehtinä on julkaisun toimittajanimien perusteella toiminut professori Risto Rinne.

Rinne pohtii laajahkossa katsauksessaan koulutuksellisen demokratian toteutumista pääasiassa koulutuksellisen kasautumisen tilastoihin tukeutuen ja kehityksen syitä tutkien. Näitä taustoitetaan niin yhteiskunnallisilla, tuotannollisilla kuin poliittisilla tekijöillä. Kaikki nämä Rinne yhdistää vahvasti mahdollisuuksien tasa-arvon ja meritokratian voittokulkuun, mikä samalla merkitsee voimakasta koulutusinstituutiokeskeisyyttä. Artikkelin lopussa Rinne esittää kaipuun sivistyksen, valistuksen ja demokratian alkuperäisiin tavoitteisiin. Lyhytkurssit ja ammatilliset tutkintopaperit eivät kuulu hänen demokratiakäsityksensä rakennusaineksiksi. Avoimeksi kysymykseksi jää, mikä sivistyksen ja demokratian alkuperäinen yhteys nykypäivänä sitten olisi.

\section{YHTEISKUNNALLISESSA}

RAUTAHÄKISSÄ

Aikuiskasvatuksen valtakunnal- lisista tieteilijöistä - näitä kirjan kaikki kirjoittajat ovat - Anja Heikkinen on myös koko SAKKE-hankkeen kirjasarjan toimituksen vetäjä. Hän rakentaa omassa (myös laajassa) artikkelissaan sukupuolen ja demokratian kysymystä pääasiassa kahdella materiaalilla: osallistumistilastoilla ja ammattikasvatuksen sukupuolittavalla historia-analyysilla. Artikkelissa on paljon luettavaa ja se jättää myös pohdittavaa yhtä lailla kuin edellinenkin. Yleistäen voidaan tiivistää, että naiset ovat "taistelleet" itsensä koulutukseen osallistujiksi ja valloittaneet etenkin vapaan sivistystyön kentän (vahva tendenssi myös muussa koulutuksessa) ja miehet ovat vetäytyneet metsiin, mökeille ja erilaisiin seuroihin. Heikkisen mukaan naiset eivät kuitenkaan ole vielä päässeet aivan yhteiskunnan yläportaille ja tarvitsevat erillisiä ohjelmia sitä varten, vaikka keskitason koulutukseen osallistuminen alkaakin olla jopa huolestuttavasti liian feminiinistä.

Heikki Silvennoinen pohtii artikkelissaan tiiviisti aikuiskoulutuksen vaikuttavuutta ja tuo ajankuvan hahmotukseen vahvaa ja tuttua turkulaista näkökulmaa etenkin työvoimapoliittisen 


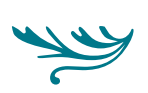

koulutuksen heikoista työllistämisvaikutuksista. Sosiologiseen otteeseen kuuluu toki määritellä myös vallan, kontrollin, integraation (sosiaalisen sulkemisen) ylläpitäminen tuonkin koulutuksen funktioiksi. Yhteiskunnallinen rautahäkki on niin vahva, että on jopa harhaanjohtavaa puhua koulutuksen vaikuttavuudesta työllisyyteen yleensä. Olemmeko turhuuksien koulutusmarkkinoilla, joissa muulla kuin työvoiman allokoinneilla eri aloille ei ole mitään merkitystä, edes kansainvälisesti? Vallan teemaa olisi koko kirjaan toivonut runsaasti enemmän ja eksplisiittisesti - nytkin sitä toki on paljon rivien välissä ja enemmän vielä jää lukijan pään varaan.

Työnantajan opissa -luvussa Kari Teräs tuo artikkelissaan työssä oppimisen historiaan tärkeän näkökulman ja samoin Pauli Kettunen omassa artikkelissaan vertaillessaan työn organisoimisen oppien kytkeytymistä työnjohdon koulutusten kehittymiseen instituutioiksi Suomessa ja Ruotsissa. Nämä katsaukset luovat reaalisten työelämäkytkentöjensä kautta ja empiiris-analyyttisellä otteella mainiosti kuvan työelämän koulutuksen erityispiirteiden kehittymisestä. Työnorganisoimisen oppien soveltamisen vaiheet ja muun muassa Ruotsin vastaavaa kehitystä vertaileva ote on arvokasta luettavaa etenkin työnsosiologiasta ja -psykologiasta kiinnostuneille.

\section{YHDISTYSTEN MUUTTUNUT LUONNE}

Matti Siisiäinen rakentaa artikkelissaan siltaa yhdistysten merkityksestä yhteiskunnan ja siten demokratian ja sivistyksen konstituutiolle. Etenkin tässä tulee esille vapaan sivistystyön kehityksen ja merkityksen perusta. Yhdistysten luonne on muuttunut maailmankatsomuksellisista enemmän opinnollisiin, mutta kokonaisuudessaan yhdistysmuotoinen sosiaalinen pääoma ei ole Suomessa hiipunut tai kriisiytynyt. Yhdistykset ovat kuitenkin eriytyneet ja muodostuneet enemmän ad hoctyyppisiksi ja "naulakkoyhteiskunnan" (Bauman) roolinvaihtoon sopiviksi eivätkä voi toimia porvarillisen yhteiskunnan hegemonian konstituutiona samoin kuin aikaisemmin. Tästä syystä niiden varaan ei ole myöskään rakennettavissa systemaattista kasvatustyötä. Vallan teeman käsittely on tässä artikkelissa hienosti sisään kirjoitettuna juonteena, ja lukijalle jää taas pohdittavaa.

Samassa kansalaistoimintaan osallistumisen luvussa Ilkka Vir- ta käsittelee kansalais- ja työväenopistojen rahoitusmuutoksia, epäselvää tehtävänkuvaa ja ottaa lopuksi maahanmuuttajien koulutuksen järjestämisen käsittelyynsä.

\section{KOULUTUKSEN UMPIPERIÄ}

Kirjan neljännessä luvussa etsitään opinpaikkoja. Erja Moore tuo tilastoihinkin nojautuen esille sen, kuinka korkeakoulutuksessa yliopistot eivät ole ottaneet paikkaansa aikuisten tutkintojen toteuttajina toisin kuin ammattikorkeakoulut. Umpiperiä alkaa faktisesti löytyä useista koulutusmuodoista, vaikka olemmekin ohittaneet muodollisesti rinnakkaiskoulutuksen ulossulkevat opintiet. Monella tavalla asia liittyy yliopistojen vanhoillisiin pedagogisiin kulttuureihin, joille esimerkiksi aikaisemmin hankitun osaamisen tunnistamiseen velvoittava Ahot-ajattelu saattaa olla samanlainen peikko kuin todellisesti pelottava taloudellisen rationaliteetin korostus.

Samassa luvussa Tero Järvinen ja Markku Vanttaja avaavat yhteisessä artikkelissaan aikuiskoulutushaluttomuuden syitä. Turkulaisittain casena on työvoimapoliittinen koulutus ja artikkelissa tehdään useita teoreettisia tarjoumia. Artikkelin lopussa kirjoittajat 
tuovat esille sinänsä tärkeitä kysymyksiä perustulosta ja työajan lyhentämisestä, mutta sen tilalla tai ainakin lisäksi olisi voinut olla toki jotakin synteesiä koulutushaluttomuudesta.

Viimeisenä artikkelina kirjan toinen toimittaja Arto Jauhiainen on käsitellyt ikäkysymyksen ja sukupolvinäkökulman sekä oppimisyhteiskunnan realiteettien yhteyksiä. Retoriikat kohtaavat realiteetteja osallistumistutkimuksen tuloksissa ja vaikkakin vanhusväestö on jo tyypitelty aktiiviseksi, todistaa oma turkulaisaineistokin muiden muassa sen, että oppimisyhteiskunnalle tärkeä tietokoneiden käyttö on ikäsidonnaista - vaikka toki asiaan vaikuttavat vahvasti muutkin tekijät kuin kronologinen ikä.

\section{AJANKUVA SIRPALEINEN}

Kovat kannet pitävät kirjaa kasassa, se on hyvin nidottu ja toimitettu, vaikka kaikki viitteet eivät olekaan lähdeluettelossa. Mahdollisesti aikakin on sirpaleinen, mutta useimmat aikalaistutkijat (yhteiskuntatieteilijät ja -filosofit) myös koostavat kirjoituksia pienistä palasista. Historiallisen kehityksen ja jatkumojen kirjoittaminen on eräs keino pitää asioita jollakin tavalla koheesiossa. Uusien merkitysten pohtimisessa saatetaan joskus tukeutua jopa itsensäkin dekonstruoineisiin teorioihin. Tästä ei tässä kirjassa ole kysymys, mutta olisiko yhteiskunnallisia merkityksiä voinut kaivaa systemaattisemmin esille vaikkapa bourdieulaiseen näkökulmaan tukeutuen? Nyt tähän kulttuuristen tapojen, erottelujen ja pääomien historialliseen kehitykseen on viitteitä Järvisen ja Vanttajan sekä Silvennoisen artikkeleissa.

Koulutuksellisen tasa-arvon filosofia on toiminut aikuiskasvatus-demokratia-yhdistelmän kantavana ja herättävänä voimana ja se on seurannut tärkeissä puheenvuoroissa useassa vaiheessa myöhemminkin (Dewey, Lindeman, Husén ym.). Nyt filosofiaan viitataan melkeinpä ainoastaan Rinteen artikkelissa. Miksi sitä nyt tarvittaisiin? Ei sen vuoksi, että Björn Wahlroos lähestyy kulman takaa "Markkinat ja demokratia”-kirjalla ja sanoo demokratiasta varmasti jotakin oleellisesti aikuiskasvatustakin koskettavaa (ks. myös uusi kirja Karppinen ja Matikainen: Julkisuus ja demokratia).

Lukijan pohdittavaksi jää myös kysymys siitä, ovatko kirjoittajat tavoittaneet uusia ja ajankuvaa koskettavia kysymyksiä aikuiskasvatuksen ja demokratian suh- teesta. Tälle on ainakin tilausta sekä teoriassa että käytännössä, kun aikuiskasvatus pyrkii rakentamaan omaa ajanmukaista identiteettiään, jota muutoin muun muassa Aikuiskasvatus-lehden kirjoituksissa on viime vuosina kovasti haettu. Tilaa saattaisi löytyä vielä sekä aikuiskasvatuksen psykohistorioille kuin myös einiin-instituutiokeskeiselle, uusia osallistumisen, kansalaisuuden ja demokratian kysymyksiä henkiin herättävälle filosofiselle avaukselle. Nyt on joka tapauksessa tartuttu tärkeään teemaan ja heitetty kysymyksiä demokratian haasteista aikuiskasvatuksessa, mikä toivottavasti saa samankaltaista jatkoa sarjan seuraavissa teoksissa.

Heikki Pasanen

FT, yliopettaja

Haaga-Helian Ammatillinen opettajakorkeakoulu 